\title{
Electronic Customer Relationship Management (E-CRM) Modeling As Efforts to Increase Customer Retention of Micro Small and Medium Enterprises (MSMEs) in Banten
}

\author{
Vidila Rosalina ${ }^{1}$, Hamdan ${ }^{2}$, Saefudin ${ }^{3}$ \\ ${ }^{1}$ Information Technology Department, Universitas Serang Raya, Banten Indonesia. \\ ${ }^{2}$ Economic Department, Universitas Serang Raya, Banten, Indonesia. \\ ${ }^{3}$ Information Technology Department, Universitas Serang Raya, Banten, Indonesia. \\ E-mail : vidila.suhendarsah@gmail.com
}

\begin{abstract}
Micro Small and Medium Enterprises (MSMEs) in Banten are still largely operated by traditional methods. Information technology has not been maximally used. Currently, modern business approach cares for customer factors intentionally, not only before but after the transaction as well. The Information Technology system used to maintain customers with the purpose of increasing customer retention which is called Customer Relationship Management (CRM). The current CRM software is more adapt to large established corporations, so it will cause some differences when applied to MSMEs. This research tried to model Electronic Customer Relationship Management (E-CRM) software tailored to the business needs of MSMEs in Banten by using local way to facilitate user in its use. The E-CRM will help MSMEs to maintain their running business by carrying out CRM to enlarge their competitiveness with other corporations and obtain a wider new market. System modeling used Zachman Frameworks to get an entire and comprehensive picture. The model of E-CRM MSMEs made in this research is expected to increase customer retention and build global market for MSMEs in Banten province.
\end{abstract}

\section{Introduction}

Nowadays, marketing is increasing very immediately and comprehend consumers is one of the strategies in the achievement of product marketing [1]. The constraints faced by most Micro Small and Medium Enterprises (MSMEs) are the constraint to market their products and sustain existing markets in addition to some other constraints such as minimum change, household finances mixed with industry finances, and traditional management. Comprehend and retaining customers become one of the strategies in business achievement. This is a major constraint to MSMEs in the midst of increasingly strong competition. MSMEs need to sustain good connections with customers and increase their loyalty through knowledge and accomplishment of customers' needs immediately and appropriately. Electronic Customer Relationship Management (E-CRM) as an information technology application will be able to solve the constraint because E-CRM's goal is to get the core of customer concept and put it in the framework of information technology use based on E-Commerce. E-CRM can help MSMEs develop new products based on a complete knowledge of customer request, market dynamics and opponents. Thus, MSMEs get a better comprehension of their customers and their needs are performed with a combination of data warehouse, data bank, and help desk or call center. This research was conducted to make E-CRM modeling on Micro Small and Medium Enterprises by using Zachman framework. There are few MSMEs who have enforced this CRM even though many MSMEs are aware of the usage of information systems to be a necessity that can not be bypassed by any business that wants to put itself in the leading position in an industry. According to Danardatu's research, CRM applications are now widely available in the market, mostly produced by American and European corporations that have already enforced CRM in their corporations. AMR Research reported, there are several CRM software providers such as Siebel Systems, Microsoft, Clarify (Nortel Networks), PeopleSoft and Oracle as market leaders. Meanwhile, professional CRM service provdiders as market leaders such as Accenture, Art Technology Group, Cambridge Technology Partners, CSC, Deloitte Consulting, EDS, eLoyalty, Cap Gemini Ernst \& Young, IBM Global Services, KPMG Consulting and Price Waterhouse Coopers. This indicates that CRM software providers are mostly overseas corporations that may make MSMEs do not want to use CRM applications into their business because the high cost of applications and the overseas vendor is still less understood in the preparation of unique small business and medium business progresses [2]. This is what motivates this research to help MSMEs in their efforts by making an easy and affordable E-CRM model. Thus the formulation of the constraint in this study: How to is the model of Electronic Customer Relationship Management (E-CRM) that is appropriate, easy and affordable for Micro Small and Medium Enterprises (MSMEs).

In general, the purpose of this research was to model Electronic Customer Relationship Management (E-CRM) in order to produce a change on Micro Small and Medium Enterprises (MSMEs) in Banten province in sustaining customer retention and extending marketing globally. Research conducted in line with the policy orders that will be pursued by the Ministry of Cooperatives and SMEs in the effort of development of Cooperatives and SMEs as mandated in the RPJMN 2015 - 2019 which is to enhance the competitiveness of Cooperatives and MSMEs so as to grow into a sustainable business with a larger scale (scaling-up) in order to help the independence of the national economy.

In 2012 there is a publication of research on small and medium enterprises (SMEs) in Malaysia (Hashim, 2012), which found that $48.8 \%$ of small and medium entrepreneurs in Malaysia have enforced information systems to help their business progresses. By using information technology to manage its business realization, SMEs in Malaysia are able to increase their competitive advantage 
in facing increasingly fierce business competition [3]. In the same year 2012, there also found a research publication that demonstrates how the concept of CRM can be enforced on small businesses to help improve and encourage the achievement of a business unit. Garcia, et al. (2012) offered a framework for implementing CRM based on case studies on MSMEs in one of the developing countries in Latin America, Mexico. Within the framework, Garcia et al. offered a CRM architecture for MSMEs that are divided into two parts: operational CRM and analytical CRM [4].

\section{Research Method}

\section{Electronic Customer Relationship Management}

E-CRM according to Whitten, J et al (2004), is a software application that gives customers access to business progresses from initial demand through service and post-sale helps. A customer information database that records all contracts that customers have with the corporation and generates customer profiles available to everyone within the corporation who need to "know the customer" [5] Meanwhile, according to John W.Satzinger et al, (2005) E-CRM is a process that helps marketing, sales, and service operations involving direct and indirect customer interactions over the internet [6]. E-CRM can be defined as activities to manage customer relationships by using the Internet, web browsers or other electronic touch points. The challenge hereby is to offer communication and information on the right topic, in the right amount, and at the right time that fits the customer's specific needs. [7]

\section{Micro Small and Medium Enterprises (MSMEs)}

Definition of MSMEs is described in the law number 20 of 2008. Definition of MSME is divided into three, which are micro, small and medium enterprises. Micro Enterprise is productive business owned by individual and/or individual business entity fulfilling the criteria of Micro Business as regulated in this Law. Small Enterprise is a stand-alone productive economic enterprise, conducted by an individual or a business entity that is not a subsidiary or not a section of a corporation owned, controlled, or becoming a part of the direct or indirect business of a medium-sized or large-scale business that meets the business criteria of Small business as defined in this Law. Medium Enterprise is a stand-alone productive economic enterprise, conducted by an individual or business entity that is neither a subsidiary nor a section of a corporation owned, controlled, nor a share either directly or indirectly with a Small Business or a large business with net worth or Annual sales proceeds as regulated in this Law.

MSME is one of the driving sectors of the Indonesian economy that can survive in facing the tight global business competition as it is today. The number of workers in the sector of MSME in early 2012 is almost 80 million people, this requires more attention to encourage MSME managers in improving business empowerment. There are several factors that influence the realization of MSMEs in sustaining business, including financing, human resources, market share, business climate, supporting facilities and infrastructure, and access to information [8].

There are several constraints that can hamper the realization of MSMEs in sustaining business. Peni Sawitri, et al (2012) said that the constraints faced by MSMEs are the difficulty of marketing their products and sustaining existing markets, and the constraints of change and financial management that have not been optimal because MSME business actors cannot survive. To be able to survive in sustaining its business, MSME is required to be able to start implementing various strategies in business development effort. Every MSMEs business actor is not only required to be able to make unique products but also must have the ability in terms of marketing the product. Without a well-supported marketing strategy, it is certain that MSMEs empowerment cannot grow rapidly [9].

\section{Zachman Frameworks}

According to Melissa A Cook (1996), John A Zachman in the late '80s introduced a framework to assist management in implementing two main things. The first thing is to separate the main components in information systems to facilitate management in planning and development. While the second thing is how to build a strategic plan from the most global level and conceptual to the technical implementation. In principle Zachman divided the information system into three major components, namely: Data, Process, and Technology which in its development into six main entities. A practitioner named John Zachman in the late ' 80 s analyzed this and gave one of his solutions that is still relevant today to be used. To commemorate his name, this framework is called the Zachman Framework. Zachman Framework is a $6 \times 6$ matrix that represents the intersection of two classification schemes - two-dimensional system architecture [10].

The Zachman Framework is expected to give comprehension of any particular aspect of a system at any point of view in system development. This tool can be useful for making decisions about changes and additions. The Zachman Framework contains six rows and six columns yielding 36 cells or aspects. ted to the contractor for the implementation process. The columns in the Zachman Framework consist of:

1. Who: representing people's relationship in the corporation. The design of the organization of the corporation must relate to the allocation of work and the authority of structure and responsibility.

2. When: representing the time or event relationship that makes performance criteria and quantitative levels for corporation resources. This is useful for designing schedules, processing architectures, control architectures, and timing devices.

3. Why: describing the corporation's motivations. It demonstrates goals and objectives, business plans, knowledge architecture, and knowledge design.

4. What: describing the entities involved in each corporation perspective. For example including business objects, system data, relational tables and definitions. 
5. How: demonstrating the functions in each perspective. For example including business progresses, software application functions, computer hardware functions, and control loop languages.

6. Where: demonstrating the locations and interconnections within the corporation. These consist of major geographical locations, separate sections within the logistics network, allocation of system nodes or even memory addressing in the system [14].

\begin{tabular}{|c|c|c|c|c|c|c|}
\hline & Why & How & What & Who & Where & When \\
\hline Contextual & $\begin{array}{l}\text { Goal } \\
\text { List }\end{array}$ & $\begin{array}{l}\text { Process } \\
\text { List }\end{array}$ & $\begin{array}{c}\text { Material } \\
\text { List }\end{array}$ & $\begin{array}{c}\text { Organizationd } \\
\text { Unit \& } \\
\text { Role List }\end{array}$ & $\begin{array}{c}\text { Geographica } \\
\text { Locations } \\
\text { List }\end{array}$ & $\begin{array}{l}\text { Event } \\
\text { List }\end{array}$ \\
\hline Conceptual & $\begin{array}{c}\text { Goal } \\
\text { Relationship }\end{array}$ & $\begin{array}{l}\text { Process } \\
\text { Model }\end{array}$ & $\begin{array}{c}\text { Entity } \\
\text { Relationship } \\
\text { Model }\end{array}$ & $\begin{array}{l}\text { Organization } \\
\text { Unit \& Role } \\
\text { Rel. Model }\end{array}$ & $\begin{array}{l}\text { Locations } \\
\text { Model }\end{array}$ & $\begin{array}{l}\text { Event } \\
\text { Model }\end{array}$ \\
\hline Logical & $\begin{array}{c}\text { Rules } \\
\text { Diagram }\end{array}$ & $\begin{array}{l}\text { Process } \\
\text { Diagram }\end{array}$ & $\begin{array}{c}\text { Data Model } \\
\text { Diagram }\end{array}$ & $\begin{array}{l}\text { Role } \\
\text { relationship } \\
\text { Diagram }\end{array}$ & $\begin{array}{l}\text { Locations } \\
\text { Diagram }\end{array}$ & $\begin{array}{l}\text { Event } \\
\text { Diagram }\end{array}$ \\
\hline Physical & $\begin{array}{c}\text { Rules } \\
\text { Specification }\end{array}$ & $\begin{array}{c}\text { Process } \\
\text { Function } \\
\text { Specification }\end{array}$ & $\begin{array}{c}\text { Data } \\
\text { Entity } \\
\text { Specification }\end{array}$ & $\begin{array}{c}\text { Role } \\
\text { Specification }\end{array}$ & $\begin{array}{c}\text { Location } \\
\text { Specification }\end{array}$ & $\begin{array}{c}\text { Evert } \\
\text { Specification }\end{array}$ \\
\hline Detailed & $\begin{array}{l}\text { Rules } \\
\text { Details }\end{array}$ & $\begin{array}{l}\text { Process } \\
\text { Detals }\end{array}$ & $\begin{array}{l}\text { Data } \\
\text { Detals }\end{array}$ & $\begin{array}{l}\text { Role } \\
\text { Details }\end{array}$ & $\begin{array}{l}\text { Location } \\
\text { details }\end{array}$ & $\begin{array}{l}\text { Event } \\
\text { Details }\end{array}$ \\
\hline
\end{tabular}

Figure 1. Zachman Framework Classification Matrix (Model of Cells Zachman Framework)

Zachman Framework does not give specific models and architectures that can be used to give a full explanation. Zachman Framework users are free to choose the tools that will be used to apply the model to be made [11].

\section{Analysis And Result}

Based on the results of observations of MSMEs in Banten province identified in above, then the E-CRM development model with local approach needs to consider some characteristics as follows [12] [13] [14]:

a. Its economic procurement is not burdensome for investment of MSMEs that tend to have small capital.

b. Using minimalist features that are often used MSMEs actors to bypass a complicated impression for the user.

c. Using the local language which is Indonesian so it is easily understood by the MSMEs actors.

d. Easy to install, easy to implement, easy to use and easy to maintain.

e. An android-based interface; this gives a familiar feel for the users in general who have often come into contact with smartphones.

f. Applications do not always need an Internet connection, so it can work online or offline.

g. Applications are based on android so that MSMEs does not need to invest in computer purchasing, but can use existing smartphone.

h. Use opensource solutions in order to bypass dependency and cost suppression.

i. Connected with a simple database backend, because in general the number of subscribers is relatively small and not too dynamic.

Stages in the framework of thinking that was carried out in E-CRM modeling research on MSMEs in Banten province is as follows:

Observation and Data Collection of MSMEs in Banten Province
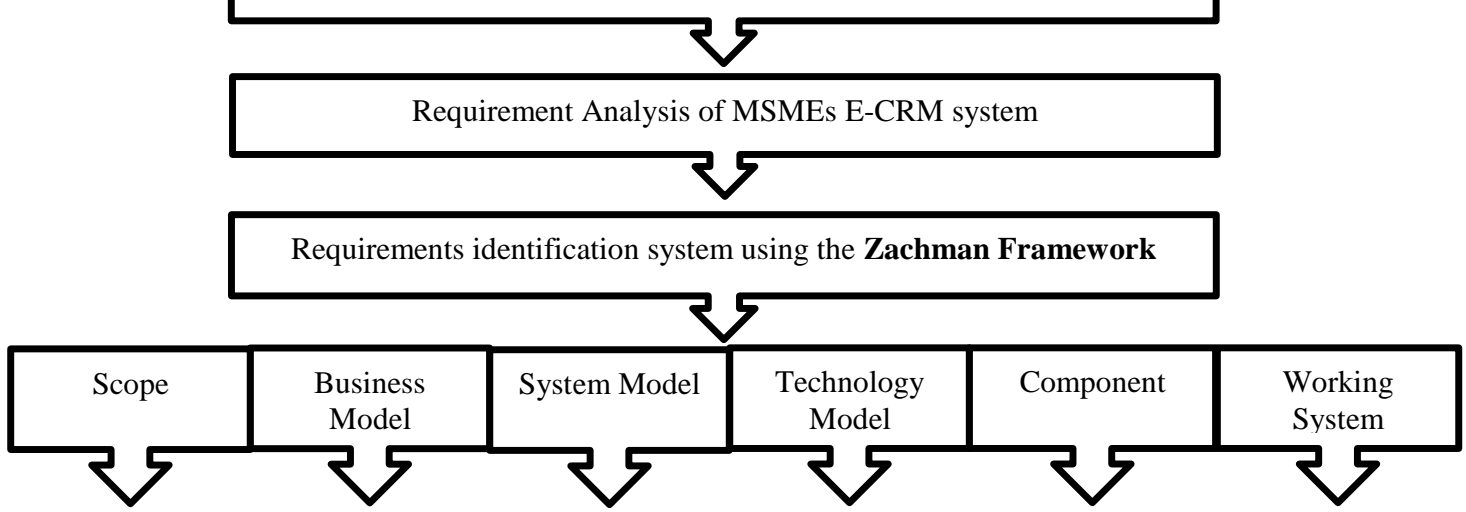
Characteristics of E-CRM Modeling with Local Wisdom to MSMEs in Banten Province [12]

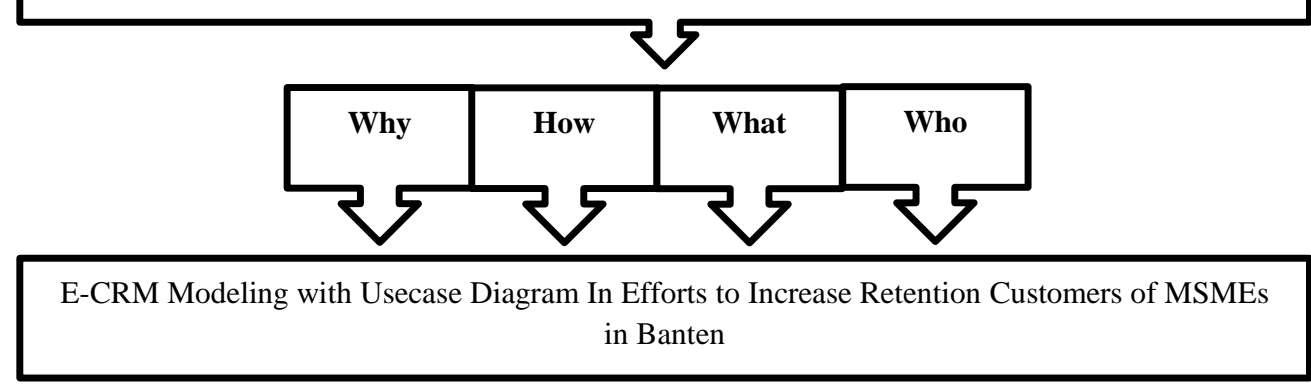

Figure 2. Stage of E-CRM Modeling for MSMEs in Banten

E-CRM modeling in efforts to increase customer retention of MSMEs in Banten by using the simplified usecase diagram (Fig.3) with 4 actors : prospective customer, customers, delivery service, admin, and 17 processes : login, registration, confirmation of registration, view product, product management, booking, reservation confirmation, testimonies, customer management, customer complaint, new product plan, delivery tracking, delivery management, promotions plan, discount scheduling, customer satisfaction management, management of complaints.

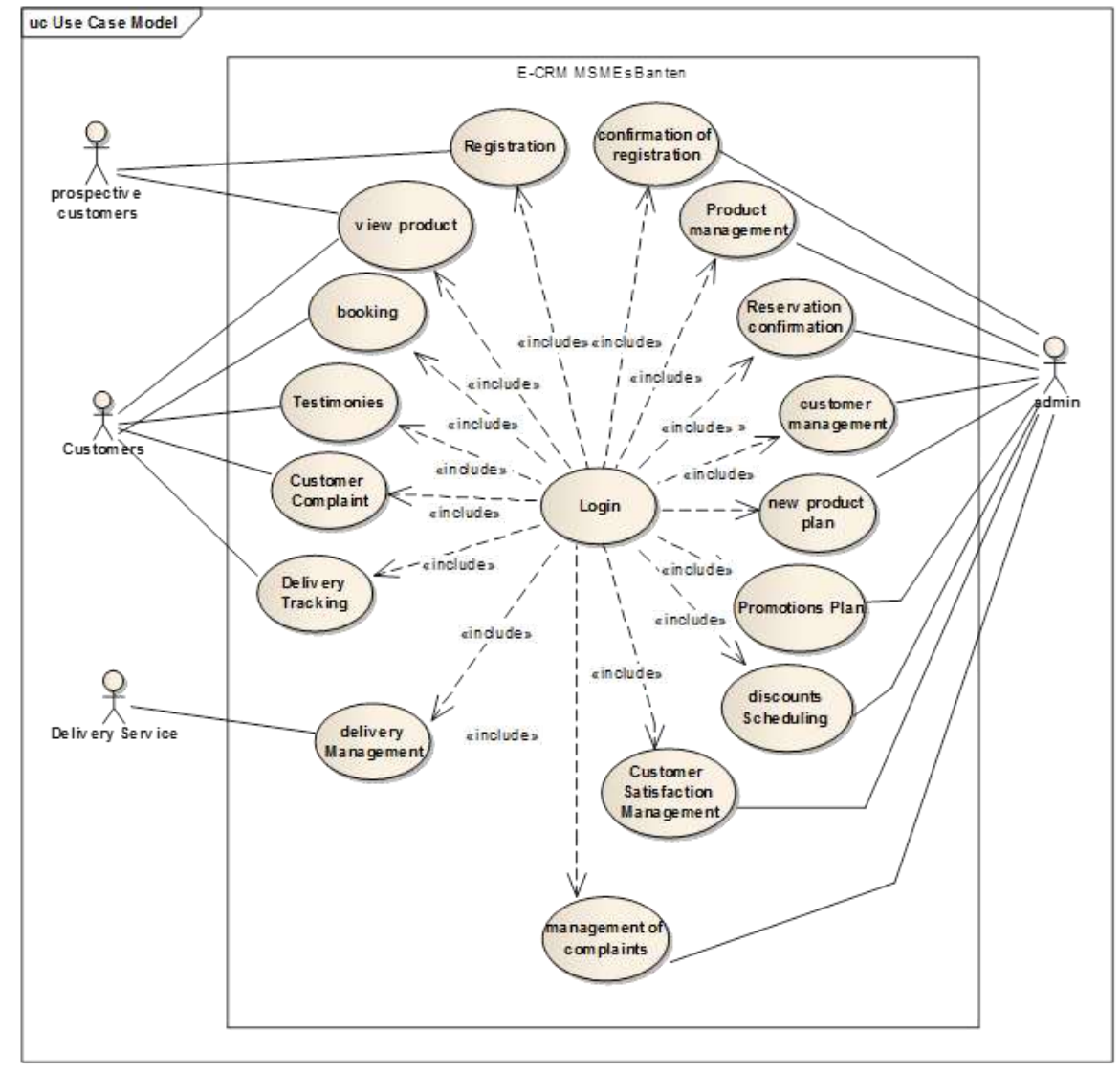

Figure 3. Usecase Diagram E-CRM MSMEs in Banten 
From the discussion of the analysis and the results described above, the following conclusions can be drawn as follows:

a. The identification of E-CRM needs for MSMEs in the Banten province by using Zachman Frameworks which consists of four columns (why, how, what, who) can produce complete and comprehensive models adjusted to the needs of MSMEs in Banten.

b. E-CRM modeling for MSMEs in Banten province uses the simplified usecase diagram with 4 actors and 17 processes because it does not require features like in large corporations but features that are adjusted to the needs of MSMEs to bring the user-friendly impression to the MSMEs actors.

\section{Acknowledgement}

The authors would like to thank the Ministry of Research Technology and Higher Education of the Republic of Indonesia (RISTEK DIKTI) for the financial support.

\section{References}

[1]. Rosalina, Vidila. 2013, Pemodelan CRM Pada Perusahaan Petrokimia menggunakan Zachman Framework, Jurnal ELECTRANS ISSN 1412-3762, Volume 12 No 2 September 2013, UPI, Bandung.

[2]. Danardatu, Aloysius Heru. 2003, Pengenalan Customer Relationship Management, Ilmu Komputer.Com

[3]. Hashim, R. 2012. Adoption of enterprise information system (EIS) in Malaysian small and medium enterprises (SMEs). Business, Engineering and Industrial Applications (ISBEIA), 2012 IEEE Symposium: 425 - 430.

[4]. Garcia, I., Pacheco, C., Martinez, A. 2012. Identifying Critical Success Factors for Adopting CRM in Small: A Framework for Small and Medium Enterprises. Software Engineering Research, Management and Applications 2012, Studies in Computational Intelligence Volume 430, 2012, pp 1-15

[5]. Whitten, Jeffery, L., Bentley, Lonnie, D., Dittman, and Kevin, C., 2004, Metode. Desain dan Analisis Sistem (diterjemahkan oleh Tim Penerjemah ANDI), Edisi 6, Yogyakarta.

[6]. Satzinger, John W., Robert B. Jackson, Stephen D Burd. 2009. Systems. Analysis and Design in a Changing World, Fifth Edition. Course Technology, Cengage Learning EMEA.

[7]. Nugraha, A., Dewi, I.N., Novianto, S. 2013. Desain Pengembangan Aplikasi Electronic Customer Relationship Management dalam Mendukung Strategi Pemasaran dan Pengelolaan Pelanggan UMKM , Konferensi Nasional Informatika (KNIF) ITB 2013.

[8]. Rifa'i, B. 2013. Efektivitas Pemberdayaan Micro Small and Medium Enterprises (UMKM) Krupuk Ikan dalam Program Pengembangan Labsite Pemberdayaan Masyarakat Desa Kedung Rejo Kecamatan Jabon Kabupaten Sidoarjo. Kebijakan dan Manajemen Publik, 130-136.

[9]. Sawitri,P., Wulandari, L., Simri, L.I.W. 2012. CRM untuk UKM, Konferensi Nasional Sistem Informasi 2012, STMIK - STIKOM Bali 23-25 Pebruari 2012.

[10]. Cook, Melissa A. 1996, Building Enterprise Information Architectures, Prentice Hall

[11]. Zachman, J.A., 2012, John Zachman's Concise Definition of the Enterprise Framework, http://www.zachman.com/aboutthe-zachman-framework.

[12]. Rosalina, Vidila., Mulyanah. 2017, Electronic Customer Relationship Management (E-CRM) Modeling on Micro, Small \& Medium Enterprises (MSMEs) Banten, International Journal of Computer Applications (0975 - 8887) Volume 176, October 2017, New York, USA.

[13]. Rosalina, Vidila, dkk. 2017. Model Electronic Customer Relationship Management (E-CRM) Menggunakan Adaptasi Bahasa Lokal Pada Usaha Mikro Kecil Menengah (UMKM) Banten, Prosiding SENASSET 2017 (Seminar Nasional Riset Terapan) ISBN 978-602-73672-0-3 : 12, November 2017.

[14]. Rosalina, Vidila, dkk. 2017. Sosialisasi Manfaat E-CRM dalam Upaya Meningkatkan Retensi Pelanggan UMKM Cilegon. Jurnal Pengabdian Masyarakat Wikrama Parahita Vol 1 No 1, November 2017. 